\title{
DETERMINATION OF RESISTANCE OF EXPERIMENTAL SOYBEANS TO THE LIMA BEAN POD BORER ETIELLA ZINCKENELLA TREITSCHKE AND THE WHITEFLY BEMISIA TABACI GENNADIUS AT DAKHLA OASES, NEW VALLEY, EGYPT
}

\author{
Mohamed A. Amro*, Mahmoud S. Omar*, Abdellah S. Abdel- \\ Moniem** \\ and Khaled M. M. Yamani*** \\ *Plant Protection Research Institute, Agricultural Research Center, Dokki, Egypt \\ **Department of Pests and Plant Protection, National Research Center, Dokki, Egypt \\ *** Field Crops Institute, Agricultural Research Center, Giza, Egypt
}

\begin{abstract}
:
Three soybean varieties and two cultivars have been planted in an isolated and closed agrodesert ecosystem in Dakhla Oases, New Valley Governorate. The resistance status of the selected soybeans against the lima bean pod borer Etiella zinckenella and the whitefly Bemisia tabaci has been determined. In respect to E. zinckenella the obtained results indicated that the tested soybean varieties Clark, Giza22 and Tono equipped higher infestation by this insect pest with an average 4.30, 3.54 and $9.13 \%$ respectively, than the tested cultivars Hagen 32 and S5 by 2.38 and $3.21 \%$, respectively. Similar results were obtained by calculating the damaged soybean seeds. The highest damage percentage appeared on Tono variety by $9.30 \%$ while, the lowest one appeared on Hagon 32 cultivar by $1.97 \%$. Also, results showed no variations between the influences of the analyzed soybean seed components on the yield consumption by E. zinckenella, whereas (r) values were nonsignificant. High compatibility is recorded between the resistance status of the tested soybeans and the mean numbers of $E$. zinckenella individuals attacking the developing pods. The newly produced cultivars Hagen32 and S5 presented some sort of resistance and appeared as moderately resistant cultivars. However, the soybean varieties Clark, Giza22 and Tono appeared as relatively resistant, susceptible and highly susceptible varieties, respectively.

Concerning the whitefly $B$. tabaci, results indicated a distinct compatibility between the nymphal incidence and the degree of resistance. Although, the tested varieties and cultivars exist different degrees of resistance, the newly produced cultivar S5 appeared as a resistant cultivar against B. tabaci infestation.

Consequently, plant breeders must be select soybean cultivars that have a desirable resistance levels for breeding purpose with serious trials to transfer gene(s) responsible for these phenomenon to the newly produced soybean varieties.
\end{abstract}




\section{INTRODUCTION:}

Soybean Glycine max (L.) Merr. is a major legume crop in tropical and subtropical areas all over the world. It received a great attention because its value as an animal feed crop and for its edible and industrialises. Its meal is the protein choice fore livestock and poultry producers worldwide. Irwin (1978) reported that the total production of soybean in north America in 1975 was $41,406,000$ tonnes. He mentioned that the Soybean Insect Research Information Center (SIRIC) has on file well over 14000 articles on soybean associated arthropods. Amongst the destructive pests that attack this crop, is the Lima Bean Pod Borer (LBPB) Etiella zinckenella Treitschke. The obvious sign of its infestation is the tine hole where the larvae escaped after the damage already has been done, whereas one larva can destroy most of the pod seeds (Semeada et al., 2001 and Tohamy and ElHafez, 2005).

On the other hand, the whiteflies were reported as severe insect pests in tropics and subtropics on several crops. The damage is done by sucking the sap from the leaves. However, fungus often grows on its honeydew (Borror and Delong, 1979). Information about the susceptibility of legume crops to Bemisia tabaci Gennadius are scarce. In Egypt, very few investigators concerned with the susceptibility of beans to $B$. tabaci (Faris et al., 1991; Nosser, 1996; Amro, 1999 and Mohamed et al., 2000).

No attempts to identify and breed soybean varieties resistant to the aforementioned pests have been done in the Egyptian Oases. Therefore, the present investigation was initiated with the aim to measure the infestation, the damage percentages and the yield loss caused by the lima bean pod borer $E$. zinckenella to three experimented soybean varieties and two cultivars that cultivated in Dakhla Oases. Also, to determine the resistance status of soybean to E. zinckenella and B. tabaci in this isolated area.

\section{MATERIAL AND METHODS:}

Field experiments were conducted throughout two successive soybean growing seasons (2004 and 2005) at Dakhla Oases, New Valley Governorate, western desert, Egypt, to evaluate the resistance status of three experimental soybean varieties and two cultivars against the infestation of the (LBPB) E. zinckenella and the whitefly $B$. tabaci. The experimental soybeans were supplied by agronomy Institute, Agricultural Research Center.

\section{The experimental area:}

An area of about $1 / 4$ feddan was divided into plots 3x3.5 meters (1/400 feddan) for each. The experimented soybeans were cultivated at the last week of May in a completely randomized block design and each variety and/or cultivar replicated 4 times.

\section{1-Infestation, damage percentages and yield loss caused by the (LBPB) E. zinckenella:}

Weekly samples were taken by picking up 25 green pods in addition to 25 dry pods from each plot after soybean pod sitting at $1^{\text {st }}$ August till collecting the yield at the end of September.

\section{1-1-Infestation percentages of soybean pods:}

The mean numbers of the larval escaping holes on the green and dry soybean pods is considered as an indicator of the infestation percentage caused by $E$. zinckenella. The infestation percentage was calculated according to the following equation as recorded by Amro (2004) in the case of the green and dry pods. 
Infested pods $(\%)=$

No. collected pods - No. undamaged pods $\times 100$

No. collected pods

\section{1-2-Damage percentages of soybean seeds:}

The collected pods were dissected to calculate the damaged and undamaged green and dry seeds. The damage percentage was calculated according to the equation used by Compton et al., (1998) with simple modification as follows:

Damage $(\%)=$

No. collected seeds - No. undamaged seeds $\times 100$ No. collected seeds

\section{1-3-Yield loss:}

The yield loss caused by this pod borer was calculated after harvest by using 25 gm. of dry soybean seeds (replicated four times). The aforementioned equation was used to calculate the yield loss percentage as follows :

Yield loss $(\%)=$

$\frac{\begin{array}{c}\text { Initial weight }- \text { Undamaged } \\ \text { weight }\end{array}}{\text { Initial weight }} \times 100$

By using additional 25 gm. dry soybean seeds (replicated four times), the correlation value (r) between the yield loss percentage and the percentage of each analyzed component was determined. Analysis of soybean components was established by the specialists in the National Research Center.

\section{2-The resistance status of the tested soybeans:}

\section{2-1-The lima bean pod borer $E$. zinckenella:}

The resistance status of the tested soybean varieties and cultivars dependent on the mean number (MN) of individuals (larvae+bores) and the amount of change (UC) from one susceptibility degree to another. Where:

UC (Range of Change $)=$

Maximum mean number - Minimum mean number 4

By using these parameters the equation applied by Nosser (1996) succeed to classify the tested soybeans into five categories. Varieties and cultivars that had mean numbers of individuals more than $(\mathrm{MN}+\mathrm{UC})$ considered highly susceptible (HS); between MN and (MN+UC), susceptible (S); less than MN to (MN-UC), relatively resistant (RR); ranging from <(MN-UC) to (MN-2UC), moderately resistant (MR) and less than (MN-2UC) were considered resistant $(\mathbf{R})$.

\section{2-2-The whitefly B. tabaci:}

The resistance status of the tested soybeans to $B$. tabaci dependent on the mean numbers of the nymphal stage individuals calculated on soybean leaves. Five trifoliate soybean leaves were picked up weekly from each plot and transferred to the laboratory in muslin bags, mean numbers of the nymphal instars of the whitefly were calculated by using stereomicroscope. The above-mentioned equation was used to determine the resistance status of each variety to this pest.

Data obtained were statistically analyzed by using $F$ test. The means were compared according to Duncan's multiple range test (Snedecor and Cochran, 1971). 


\section{RESULTS AND DISCUSSION:}

1-Infestation, damage percentages and yield loss caused by the (LBPB) E. zinckenella:

\section{1-1-Infestation percentages of soybean pods:}

The mean percentage of the infested soybean pods by the (LBPB) E. zinckenella is shown in Table(1). Statistical analysis of the data revealed highly significant differences between the infestation percentages of the tested soybeans $(\mathrm{F}=66.27 * *)$. The obtained results in the two successive years are quietly similar. The soybean varieties Clark, Giza22 and Tono equipped higher infestation by $4.30 ; 3.54$ and $9.13 \%$ respectively, than the soybean cultivars Hagen32 and $\mathrm{S} 5$ by 2.38 and $3.21 \%$, respectively. These newly experimented cultivars may be used as promising varieties because their low infestation. In this respect Semeada et al., (2001) determined the damage caused by the (LBPB) E. zinckenella to soybean according to the different levels of infestation by this insect pest.

\section{1-2-Damage percentages of soybean seeds:}

Because the (LBPB) E. zinckenella spends its destructive larval stage inside the developing legume pods and feeds on developing seeds before leaving the pod through an escape hole, results in (Table 2) dependent on this behavior to measure the damage percentage caused by this insect pest on the tested soybean seeds. Tabulated data showed highly significant differences between the tested soybean seeds $(\mathrm{F}=84.44 * *)$. Similar, results have been obtained during each of the two studied years. The damage percentage is quietly high on soybean varieties than on soybean cultivars. The highest damage percentage appeared on Tono variety and represented by $9.30 \%$, while the lowest one appeared on the soybean cultivar Hagen32 by $1.97 \%$ throughout the studied period. SegarraCarmona and Barbosa (1990) dependent on this parameter to evaluate the herbivory levels by E. zinckenella on Glycine max and Crotalaria pallida.

\section{1-3-Yield loss:}

Data presented in Table (3) exhibit the percentages of the yield loss after harvest. Highly significant differences between the tested soybeans $(F=7.02 * *)$ were recorded. Although, the soybean varieties Tono, Giza22 and Clark showed high yield loss by $4.05,3.21$ and $2.39 \%$ respectively, the tested cultivars $\mathrm{S} 5$ and Hagen 32 showed low yield loss by 0.94 and $0.83 \%$, respectively. In this approach similar results have been reported by Amro (2004) by using different cowpea cultivars. On the other hand, the analysis of the available soybean components (Protein, Fibers, Ash and Relative humidity \%) was represented in Table (3). This approach have been conducted to find what component responsible about the low populations compared with the high populations of E. zinckenella. Results showed no variations between the influences of the analyzed soybean components on the yield loss, whereas (r) values were nonsignificant in all cases. Therefore, factors responsible for soybean resistance to E. zinckenella need more studies in the future.

Table (1): The mean percentage of the infested green and dry soybean pods by Etiella zinckenella during 2004 and 2005 growing seasons

\begin{tabular}{||c|c|c|c|c|c|c|c||}
\hline \multirow{2}{*}{$\begin{array}{c}\text { Varieties and } \\
\text { cultivars }\end{array}$} & \multicolumn{3}{|c|}{ 2004 growing season } & \multicolumn{2}{c|}{ 2005 growing season } & \multirow{2}{*}{$\begin{array}{c}\text { General } \\
\text { mean } \pm \text { SD }\end{array}$} \\
\cline { 2 - 8 } & Green pods & Dry pods & Mean \pm SD & Green pods & Dry pods & Mean \pm SD & 4.30 $\pm 1.5 \mathrm{~b}$
\end{tabular}




\begin{tabular}{|c|c|c|c|c|c|c|c|}
\hline Giza22 & $3.00 b$ & $3.00 \mathrm{~cd}$ & $3.00 \pm 0.6 \mathrm{~cd}$ & $2.83 b$ & $5.33 b$ & $4.08 \pm 1.5 b$ & $3.54 \pm 1.2 \mathrm{c}$ \\
\hline Hagen32 & $2.66 \mathrm{~b}$ & $2.66 d$ & $2.66 \pm 0.4 d$ & $1.50 \mathrm{~b}$ & $2.67 c$ & $2.09 \pm 0.8 c$ & $2.38 \pm 0.7 d$ \\
\hline S5 & $2.83 b$ & $4.33 c$ & $3.58 \pm 0.9 \mathrm{c}$ & 2.33b & $3.33 c$ & $2.83 \pm 0.9 b c$ & $3.21 \pm 1.0 \mathrm{c}$ \\
\hline Mean & 3.43 & 5.53 & 4.48 & 3.73 & 5.33 & 4.58 & 4.51 \\
\hline F. value & 70.70** & $75.81 * *$ & $80.07 * *$ & $40.33 * *$ & 44.05** & $56.57 * *$ & $66.27 * *$ \\
\hline
\end{tabular}

Based on 25 soybean pods/each replicate

Means in each column followed with the same letter are not significantly different at 0.05 level of probability.

** Highly significant at 0.05 level of probability.

Table (2): The mean percentage of the damaged green and dry soybean seeds infested by Etiella zinckenella during 2004 and 2005 growing seasons

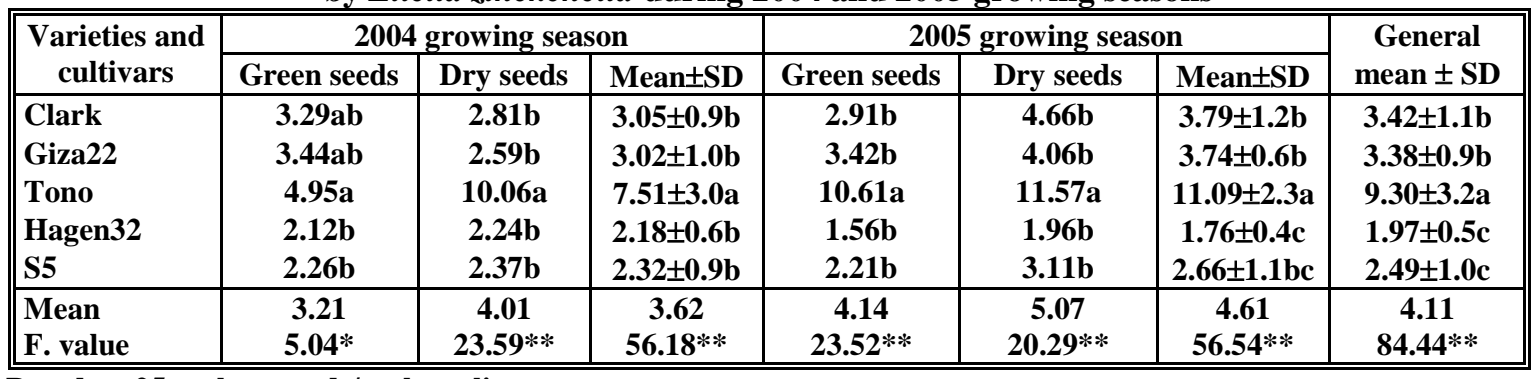

Based on 25 soybean pods/each replicate.

Means in each column followed with the same letter are not significantly different at 0.05 level of probability.

* Significant at $\mathbf{0 . 0 5}$ level of probability, ** Highly significant at 0.01 level of probability.

Table (3): Relationship between certain soybean components and the yield loss caused by Etiella zinckenella

\begin{tabular}{|c|c|c|c|c|c|}
\hline $\begin{array}{c}\text { Varieties and } \\
\text { cultivars }\end{array}$ & $\begin{array}{c}\text { Protein } \\
(\%)\end{array}$ & $\begin{array}{c}\text { Fibers } \\
(\%)\end{array}$ & $\begin{array}{l}\text { Ash } \\
(\%)\end{array}$ & $\begin{array}{l}\text { RH } \\
(\%)\end{array}$ & $\begin{array}{r}\text { Yield loss } \\
(\%)\end{array}$ \\
\hline Clark & 35.84 & 13.47 & 4.75 & 6.67 & $2.39 \mathrm{ab}$ \\
\hline (r) value & 0.751 & 0.918 & -0.751 & 0.013 & - \\
\hline Giza 22 & 36.19 & 12.76 & 4.38 & 6.61 & $3.21 \mathrm{a}$ \\
\hline (r) value & - 0.068 & 0.426 & 0.426 & - 0.629 & - \\
\hline (r) value & 0.321 & 0.241 & 0.321 & - 0.893 & - \\
\hline Hagen 32 & 36.27 & 12.10 & 4.51 & 6.84 & 0.83 b \\
\hline (r) value & 0.607 & 0.607 & - 0.618 & - 0.607 & - \\
\hline S5 & 33.41 & 8.82 & 4.67 & 6.35 & 0.94 b \\
\hline
\end{tabular}

Based on 25 gm. dry soybean seeds.

Means followed by the same letter are not significantly different at 0.05 level of probability. ns= non significant.

** Highly significant at 0.01 level of probability.

\section{2-The resistance status of the tested soybeans:}

\section{2-1-The Lima bean pod borer \\ E. zinckenella :}

The tiny holes (Bores) refer to the escape larvae before sampling. So, the number of these bores in addition to the number of larvae inside the developing pods expressed about the number of individuals (Bores+larvae). Results presented 
in Table (4) summarizes the mean numbers of individuals in the dissected green and dry pods and the resistance status of soybean varieties and cultivars. Data revealed highly significant differences between the tested soybeans $(\mathrm{F}=84.25 * *)$. The soybean varieties Tono, Giza32 and Clark harbored mean numbers of individuals higher than the soybean cultivars S5 and Hagen32 by mean numbers 2.42, 1.32, 0.93 and $0.60,0.47$, respectively.

Although, some of the tested soybeans showed some sort of resistance, no one appeared immune to the pod borer infestation. Regarding the resistance status throughout the two successive growing seasons, the soybean varieties Tono, Giza22 and Clark appeared as Highly Susceptible (HS), Susceptible (S) and Relatively resistant (RR) varieties. However, the soybean cultivars Hagen32 and S5 exist some sort of resistance and appeared as Moderately resistant (MR) cultivars. Similar results have been reported by Talekar and Chen (1983) and Talekar and Lin (1994) who identified sources of resistance to the (LBPB) in soybean. In general, the obtained results may be consider the newly produced soybean cultivars as a promising varieties that can be use as resistant varieties to this insect pest in the future.

Table (4): Resistance status of soybean varieties and cultivars to the lima bean pod borer Etiella zinckenella

\begin{tabular}{|c|c|c|c|c|c|c|c|c|}
\hline \multirow{3}{*}{$\begin{array}{c}\text { Varieties } \\
\text { and cultivars }\end{array}$} & \multicolumn{6}{|c|}{ Mean No. of (bores+larvae) } & \multirow{3}{*}{$\begin{array}{c}\text { General } \\
\text { mean } \pm \text { SD }\end{array}$} & \multirow{3}{*}{$\begin{array}{l}\text { Resistance } \\
\text { status }\end{array}$} \\
\hline & \multicolumn{3}{|c|}{2004 growing season } & \multicolumn{3}{|c|}{2005 growing season } & & \\
\hline & Green pods & Dry pods & Mean \pm SD & Green pods & Dry pods & Mean \pm SD & & \\
\hline Clark & $0.50 b$ & $1.66 \mathrm{~b}$ & $1.08 \pm 0.8 b$ & $0.54 b$ & $1.00 \mathrm{~b}$ & $0.77 \pm 0.3 b$ & $0.93 \pm 0.6 c$ & $\mathbf{R R}$ \\
\hline Giza22 & $0.38 b$ & 3.00a & $1.69 \pm 1.8 \mathrm{a}$ & $0.79 b$ & $1.08 b$ & $0.94 \pm 0.3 b$ & $1.32 \pm 1.3 \mathrm{~b}$ & $\mathbf{S}$ \\
\hline Tono & $1.29 \mathrm{a}$ & 3.16a & $2.23 \pm 1.2 \mathrm{a}$ & 2.71a & 2.50a & $2.61 \pm 0.5 a$ & $2.42 \pm 0.9 \mathrm{a}$ & HS \\
\hline Hagen32 & $0.25 b$ & $0.75 b c$ & $0.50 \pm 0.3 b c$ & $0.29 b$ & $0.58 b$ & $0.44 \pm 0.4 b$ & $0.47 \pm 0.3 d$ & MR \\
\hline S5 & $0.59 b$ & $0.33 \mathrm{c}$ & $0.46 \pm 0.3 c$ & $0.62 b$ & $0.83 b$ & $0.73 \pm 0.3 b$ & $0.60 \pm 0.3 d$ & MR \\
\hline \begin{tabular}{|l|} 
Mean \\
F value
\end{tabular} & $\begin{array}{c}0.60 \\
11.18 * *\end{array}$ & $\begin{array}{c}1.78 \\
15.38 * *\end{array}$ & $\begin{array}{c}1.19 \\
17.55^{* * *}\end{array}$ & $\begin{array}{c}0.99 \\
11.99 * *\end{array}$ & $\begin{array}{c}1.20 \\
16.94 * *\end{array}$ & $\begin{array}{c}1.09 \\
31.72 * *\end{array}$ & $\begin{array}{c}1.14 \\
8425 * *\end{array}$ & \\
\hline
\end{tabular}

Based on 25 soybean pods/each replicate.

Means in each column followed with the same letter are not significantly different at 0.05 level of probability.

** Highly significant at 0.01 level of probability.

HS =Highly susceptiblele, $\mathrm{S}=$ Susceptible, $\mathrm{RR}=$ Relatively resistant, $\mathrm{MR}=$ Moderately resistant.

\section{2-2-The whitefly B. tabaci:}

Data presented in Table (5) exhibit the nymphal average numbers and the resistance status of the tested soybeans to the whitefly $B$. tabaci during the period of study. Statistical analysis of the data revealed significant differences between the tested cultivars $(F=$ 4.76*). The tested soybeans were arranged descendingly according to the nymphal infestation as follows: Tono by $39.93>$ Hagen32 by $34.47>$ Clark by $31.57>$ Giza22 by $28.23>$ S5 by 22.85 mean numbers, respectively.

The obtained results indicated a distinct compatibility between the nymphal incidence and the degree of resistance. By using the aforementioned equation, Tono variety appeared as a highly susceptible (HS) variety. However, Clark and Hagen32 appeared as susceptible(S) soybeans. In contrast, Giza22 and S5 exhibit some sort of resistance and appeared as relatively resistant (RR) and resistant (R) soybeans, respectively. So, it is of importance to point out herein to the soybean cultivar $\mathrm{S} 5$ as a moderately resistant (MR) and resistant (R) cultivar against both of $E$. zinckenella and $B$. tabaci, respectively. The resistance mechanism of this newly produced cultivar against E. zinckenella may be due to appearance of 
antibiosis phenomenon which needs more studies in the future. However, its resistance mechanism against $B$. tabaci could be due to the hooked-trichomes density which can deter the adult ovipositor from reaching to the leaf surface as reported by Pillemer and Tingey
(1976). Therefore, it can be concluded that the newly produced soybean cultivar (S5) must be take great attention in the future to be used as resistant (R) variety against the LBPB E. zinckenella and the whitefly $B$. tabaci.

Table (5): Resistance status of soybean varieties and cultivars to the whitefly Bemisia tabaci

\begin{tabular}{|c|c|c|c|c|}
\hline \multirow{2}{*}{$\begin{array}{c}\text { Varieties and } \\
\text { cultivars }\end{array}$} & \multicolumn{3}{|c|}{ Mean No. of nymphs/5 trifoliate leaves } & \multirow{2}{*}{$\begin{array}{c}\text { Resistance } \\
\text { status }\end{array}$} \\
\hline & 2004 growing season & 2005 growing season & Mean \pm SD & \\
\hline Clark & 32.95ab & 30.19ab & $31.57 \pm 4.7 \mathrm{abc}$ & $\mathbf{S}$ \\
\hline Giza22 & 30.14ab & $26.33 \mathrm{bc}$ & $28.23 \pm 7.2 b c$ & $\mathbf{R R}$ \\
\hline Tono & 44.62a & $35.24 a$ & $39.93 \pm 6.4 a$ & HS \\
\hline Hagen32 & 36.81ab & 32.14ab & $34.47 \pm 4.4 \mathrm{ab}$ & $\mathbf{S}$ \\
\hline S5 & $25.09 b$ & $20.62 \mathrm{c}$ & $22.85 \pm 4.5 c$ & $\mathbf{R}$ \\
\hline \begin{tabular}{|l|} 
Mean \\
F. value
\end{tabular} & $\begin{array}{c}32.92 \\
3.02 \\
\text { NS }\end{array}$ & $\begin{array}{c}28.90 \\
10.15 * *\end{array}$ & $\begin{array}{l}30.91 \\
4.76^{*}\end{array}$ & \\
\hline
\end{tabular}

Based on 5 trifoliate leaves/each replicate.

Means in each column followed with the same letter are not significantly different at 0.05 level of probability. NS, non significant, $*$ Significant at 0.05 level of probability, $* *$ Highly significant at 0.01 level of probability. HS= Highly susceptible, $\mathbf{S}=$ Susceptible, $\mathbf{R R}=$ Relatively resistantt, $\mathrm{R}=$ Resistant

\section{REFERENCES:}

Amro, M.A. (1999): Ecobiological studies on certain arthropod pests infesting selected cowpea cultivars and control strategy in arid-ecosystem. Ph.D. Thesis, Fac. Agric. Assiut Univ., Egypt.

Amro, M.A. (2004): The influence of plant characteristics on the field infestation and resistance status of certain cowpea cultivars to the lima bean pod borer Etiella zinckenella Treitschke and the southern cowpea weevil Callosobruchus maculatus (Fabricius). The Sec. Int. Conf. for Develop. and Env. in the Arab world, Assiut Univ. March 23-25: 375-384.

Borror, D.J. and D.M. Delong (1979): An introduction to the study of insects. $3^{\text {rd }}$ ed. Holt, Rinehart and Winston. N.Y.

Compton, J. A. F.; S, Floyd; A. Ofosu and B. Agho. (1998): The modified count and weight method: an improved procedure for assessing weight loss in stored maize gobs. J. Stored Prod. Res. 34: 272-285.
Faris, F. S.; M.K. Megali; Y.S. Khafagi and K.H.M. Adam (1991): Susceptibility of some beans cultivars to whitefly, mites and rust diseases with special references to field and pod characteristics. Fourth Arab Cong. of Plant Protection. Cairo, Dec.: 1-5.

Irwin, M. E. (1978): Soybean pest management in USA and their control. In. Singh, S.R.; H.F. Van Emden and T. A. Taylor. (Ed.). Pests of grain legumes: Ecology and Control. Academic Press Inc. London, New York.:141-150.

Mohamed, S. H.; F. A. Abdel-Galil; M. A. Morsi and M. A. Amro. (2000): Susceptibility of cowpea cultivars to natural infestation with whitefly, Bemisia tabaci Gennadius and the two-spotted spider mite, Tetranychus urticae Koch. Proceedings of the $2^{\text {nd }}$ Scientific Conf. Agric. Sci., Assiut Univ. Egypt,: 601-611.

Nosser, M. A. (1996): Mechanism of resistance in bean and cowpea varieties to certain 
sucking insects infestation. M.Sc. Thesis, Fac. Agric., Cairo Univ., Egypt.

Pillemr, E. A. and W.M. Tingey (1976): Hooked Trichomes: A physical plant barrier to a major agricultural pest. Science, N.Y., 193: 482-484.

Segarra-Carmona, A. and P. Barbosa (1990): Influence of patch plant density on herbivory level by Etiella zinckenella (Lepidoptera: Pyralidae) on Glycine max and Crotalaria pallida. Environ. Entomol. 19 (3): 640-647.

Semeada, A. M.; H.A. Salem; S. Elnagar and M.H. Mansour (2001): Infestation and threshold levels of the lima bean pod borer Etiella zinckenella (Treitschke) on soybean crop. Proceedings of the $1^{\text {st }}$ Congress on Integrated Pest Management. Cairo Univ.: 141-148.
Snedecor, G.W. and G.W. Cochran (1971): Statistical methods. Iowa State Univ. Press, Amer, Iowa, USA.

Talekar, N.S. and B.S. Chen (1983): Identification of sources of resistance to lima bean pod borer (Lepidoptera: Pyralidae) in Soybean. J. Econ. Entomol. 76: 38-39.

Talekar, N.S. and C.P. Lin (1994): Characterization of resistance to lima bean pod borer (Lepidoptera: Pyralidae) in soybean. J. Econ. Entomol. 87(3): 821-825.

Tohamy, H.T. and G. A. El-Hafez (2005): Integrated crop management system for controlling cowpea pod worm, Etiella zinckenella (Treit.). in relation to soybean yield at Minia and new valley regions. Egypt. J. Agric. Res. 83 (3): 1079-1098. 


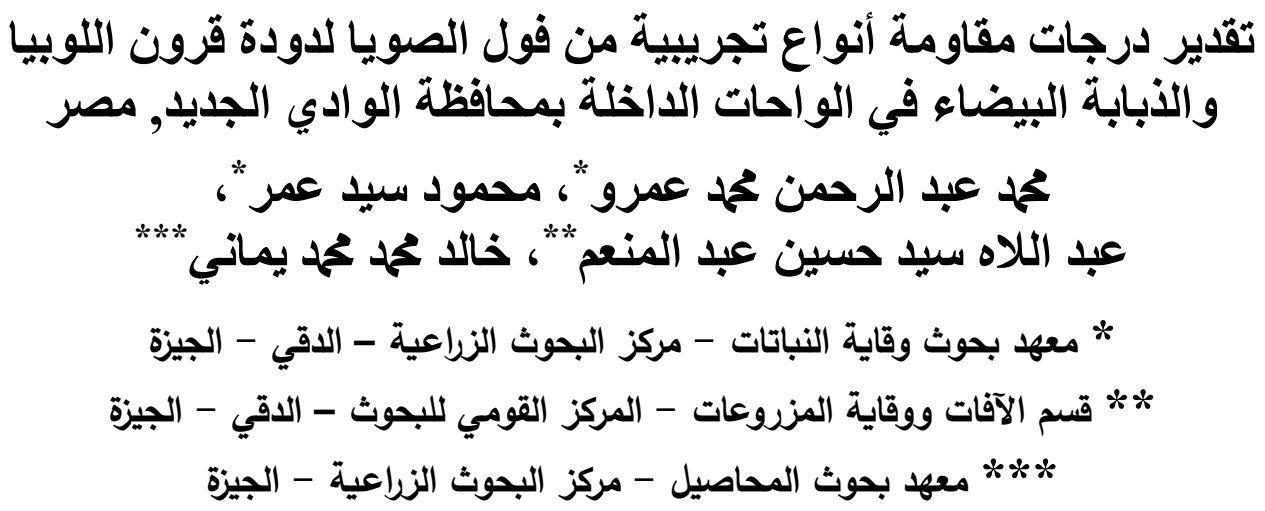

أجريت الدراسة بزراعة ثلاث أصناف وسلالتين من فول الصويا في منطقة منعزلة شبه صحراوية بالواحات الداخلة بمحافظة الوادي الجديد. وقد تم تقدير درجات مقاومة هذه الأصناف والسلالات للإصابة بدودة قرون اللوبيا Bemisia tabaci (Gennadius) Etiella zinckenella Treitschke

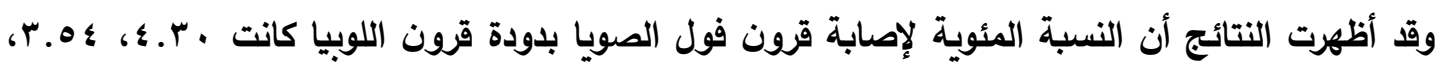

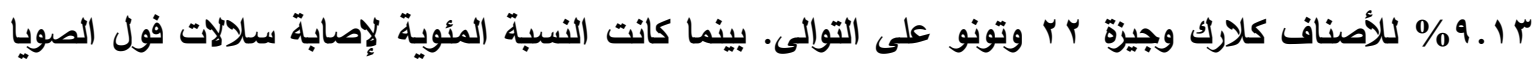

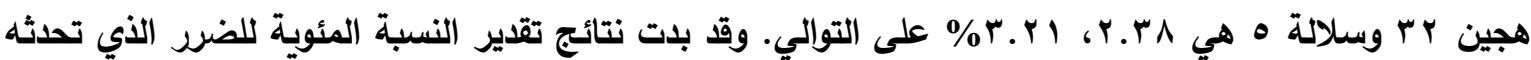

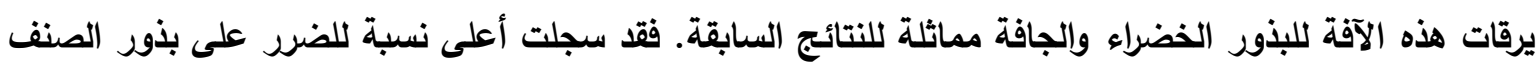

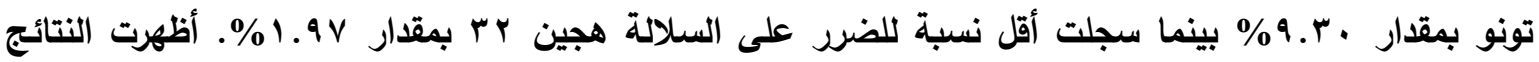
أيضا عدم وجود اختلافات بين تأثيرات بعض مكونات بذور فول الصويا على استهلاك دودة قرون اللوبيا, حيث كان

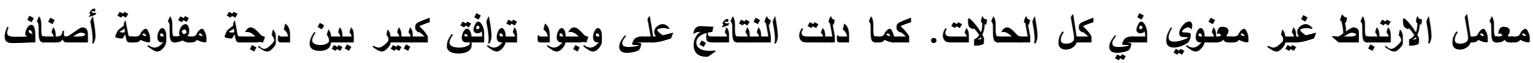

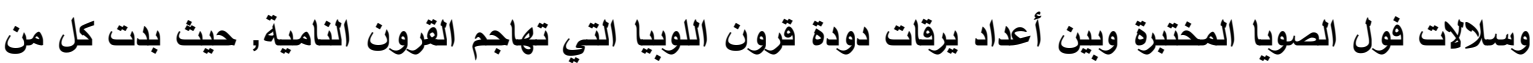

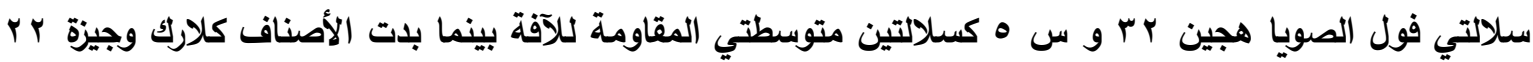
وتونو كأصناف أقل مقاومة وحساسة وعالية الحساسية للآفة على التوالي.

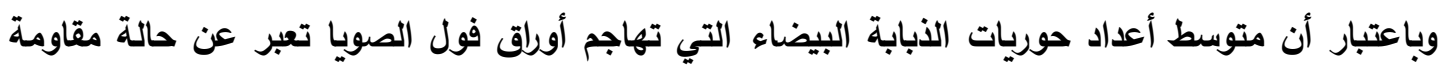
النبات للآفة فقد أظهرت النتائج توافق كبير بين متوسط أعداد الحوريات على الأورلق ودرجة حساسية الأصناف المختبرة للآفة. وبالرغم من ظهور درجات مختلفة من الحساسية للآفة بين الأصناف والسلالات المختبرة إلا أن الن الأن السلالة س ه ظهرت كسلالة مقاومة للابابة البيضاء. وبناءً على ذلك يمكن توجيه مربي النباتات إلى اختيار السلالات والأصناف التي تحمل مستويات مرغوبة من المقاومة لكلٍ من دودة قرون اللوبيا والذبابة البيضاء في برامج التربية مع عمل محاولات جادة لنقل الجينات المسئولة عن هذه الصفات للأصناف المنتجة حديثاً. 